University of Nebraska - Lincoln

DigitalCommons@University of Nebraska - Lincoln

Publications from USDA-ARS / UNL Faculty

U.S. Department of Agriculture: Agricultural

Research Service, Lincoln, Nebraska

November 1998

Dry-matter partitioning and leaf area of winter wheat grown in a long-term fallow tillage comparisons in the US Central Great

Plains

Wallace Wilhelm

University of Nebraska-Lincoln, wwilhelm1@unl.edu

Follow this and additional works at: https://digitalcommons.unl.edu/usdaarsfacpub

Part of the Agricultural Science Commons

Wilhelm, Wallace, "Dry-matter partitioning and leaf area of winter wheat grown in a long-term fallow tillage comparisons in the US Central Great Plains" (1998). Publications from USDA-ARS / UNL Faculty. 108. https://digitalcommons.unl.edu/usdaarsfacpub/108

This Article is brought to you for free and open access by the U.S. Department of Agriculture: Agricultural Research Service, Lincoln, Nebraska at DigitalCommons@University of Nebraska - Lincoln. It has been accepted for inclusion in Publications from USDA-ARS / UNL Faculty by an authorized administrator of DigitalCommons@University of Nebraska - Lincoln. 


\title{
Dry-matter partitioning and leaf area of winter wheat grown in a long-term fallow tillage comparisons in the US Central Great Plains
}

\author{
W.W. Wilhelm* \\ US Department of Agriculture, Agricultural Research Service, 119 Keim Hall, University of Nebraska, Lincoln, NE 68583-0934, USA
}

Received 24 September 1997; accepted 3 April 1998

\begin{abstract}
Crop management practices (tillage, residue management, fertilization, etc.) define the soil environment to which crops are exposed and through these environmental conditions control crop growth. The purpose of this paper is to report the response of winter wheat (Triticum aestivum $\mathrm{L}$.) to long-term (10 years) application of fallow tillage practices (plow, sub-till, and no-till) and $\mathrm{N}$ fertilization in terms of above- and below-ground dry-matter partitioning. During 1978 , less winter wheat root tissue was produced in the sub-till treatment compared to the average of the plow and no-till treatments. However, in 1979, all treatments produced the same amount of root tissue. Averaged over all treatments, root tissue was ca. $7 \%$ of the above-ground dry-matter production. During 1979, less above-ground dry matter was produced at late grain fill (27 June) with addition of N fertilizer $\left(929 \mathrm{~g} \mathrm{~m}^{-2}\right)$ than when $\mathrm{N}$ was not applied $\left(957 \mathrm{~g} \mathrm{~m}^{-2}\right)$. In contrast, during 1980 (at about the same stage of development), application of $\mathrm{N}$ resulted in more above-ground dry-matter production in the plow and no-till treatments, but addition of $\mathrm{N}$ reduced production in the sub-till treatment. Grain yield followed similar trends. Nitrogen application also increased tiller production and number of tillers surviving to maturity. Nitrate reductase activity was measured to determine if the reported lesser levels of nitrate- $\mathrm{N}$ in soils under reduced tillage management changed $\mathrm{N}$ metabolism of the plant. Nitrate reductase activity differed among $\mathrm{N}$ rates (when measured after $\mathrm{N}$ application), but did not differ among tillage treatments. (C) 1998 Published by Elsevier Science B.V. All rights reserved.
\end{abstract}

Keywords: Wheat; Root distribution; Tillage; $\mathrm{N}$ fertilization; Leaf area index; Nitrate reductase

\section{Introduction}

Crop development and growth are intimately linked to the environment to which the crop plant is exposed (Bond et al., 1971; Wilhelm et al., 1987, 1989). In nonirrigated agriculture, fertilization, tillage, and residuemanagement practices are the main ways in which producers modify the soil environment to enhance

\footnotetext{
*Corresponding author. Tel.: +1 402-472-1512; fax: +1 402-4720516; e-mail: wwilhelm@unlinfo.unl.edu
}

crop production. The soil environment has an influence, not only on root development, but also on top growth (Barraclough, 1984; Bennie et al., 1987; Peterson et al., 1984; Wilhelm and Mielke, 1988). Peterson et al. (1984) reported that use of smaller pots $(0.171$ vs. 3.40 l) to grow winter wheat (Triticum aestivum L.) in a glass-house experiment resulted in reduced leaf number, leaf size, tiller number, main stem height, and plant dry matter even if plants were supplied with adequate water and nutrients. Wilhelm and Mielke (1988) found that soil bulk density and the presence of 
compacted soil layers (simulated tillage pan) can reduce growth of wheat shoots and roots. Similar results were reported by Oussible et al. (1992) for a field study conducted in Morocco. Temperature, water, and nutrient regimes established under specific management practices can affect top growth directly (Power et al., 1986; Wilhelm et al., 1986), and indirectly, through modifications of root development (Merrill et al., 1996).

Tillage and $\mathrm{N}$-fertilization practices may have direct or indirect impact on plant processes other than root growth. In terms of crop productivity, dry-matter partitioning and leaf area development are critical factors determining light interception, and through it, crop yield (Milthorpe and Moorby, 1974). In addition, Broder et al. (1984) suggested that reduced tillage and no-till cropping systems can be characterized as having less $\mathrm{NO}_{3}-\mathrm{N}$ in the surface $30 \mathrm{~cm}$ of soil compared to conventionally tilled systems. Because nitrate reductase activity in the plant responds quickly to changes in $\mathrm{NO}_{3}$ level (Chantarotwong et al., 1976; Neerajdatta et al., 1981); if there is less $\mathrm{NO}_{3}-\mathrm{N}$ in the no-till system, it is hypothesized that nitrate reductase activity of winter wheat would be reduced in no-till fallow systems compared with tilled systems. The purpose of the research summarized in this report was to evaluate the above- and below-ground growth, partitioning, and nitrate reductase activity of winter wheat in response to specific fallow-tillage and nitrogen-fertilization practices applied over an extended period (10 years).

\section{Materials and methods}

These data were collected during the years of 1978 through 1981 on the Previously Cultivated site of a long-term winter wheat-fallow experiment near Sidney, NE, USA, on an Alliance silt loam soil (fine-silty, mixed, mesic Aridic Argiustoll). Details on the experimental site and cultural practices have been given by Fenster and Peterson (1979) and Lyon et al. (1998).

\subsection{Root data}

Root samples were collected in the growing wheat from tillage and fertilizer treatments during the fifth winter-wheat-fallow cycle (1978 and 1979). Techniques used were similar to those described by Wilhelm et al. (1982). Summarized data from the 1978 season were reported there. In 1979, samples were collected using a Giddings ${ }^{1}$ hydraulic soil sampler equipped with a $76-\mathrm{mm}$ diameter by $1.20-\mathrm{m}$ long probe. One sample was taken midway between the seeded rows in areas where no wheel traveled during planting. At each sampling date, cores were divided into $0.15-\mathrm{m}$ long segments, placed in plastic bags, and stored at $4^{\circ} \mathrm{C}$. Cores were extracted to $1.20 \mathrm{~m}$ on 18 April, 24 May, and 27 June. Individual soil cores were soaked for $2 \mathrm{~h}$ in a calcium metaphosphate (Calgon) solution and washed by hand over a 50-mesh sieve (openings $<0.33 \mathrm{~mm}$ ). Root material retained on the sieve was stored in a $50 \%(\mathrm{v} / \mathrm{v})$ aqueous solution of ethyl alcohol. Samples were later dried at $80^{\circ} \mathrm{C}$ for $24 \mathrm{~h}$ and weighed.

\subsection{Leaf area and above-ground dry matter}

Above-ground dry matter was collected several times during 1979,1980 , and 1981 by clipping three 1 -m row segments at a height of $50 \mathrm{~mm}$. Plant material was weighed and water content determined by drying a sub-sample to a constant weight at $60^{\circ} \mathrm{C}$. An additional sub-sample of 50 culms, representing the range in culm size and age in the total sample, was collected to determine leaf area. All leaf blades were separated from the sheath at the collar and leaf blade area determined with a Lambda 3000 leaf-area meter. Specific leaf weight (SLW, ratio of leaf-blade weight to leaf-blade area) and leaf weight fraction (ratio of leaf-blade weight to sub-sample weight) were calculated and used to determine leaf area index (LAI). Leaf area ratio (LAR, ratio of leaf-blade area to total aboveground plant weight) was also calculated. Tiller number was determined by measuring the length of row occupied by 250 tillers and converted to tiller $\mathrm{m}^{-2}$. Grain yield was determined by collecting grain from above-ground samples collected as described above at physiological maturity.

\footnotetext{
${ }^{\mathrm{l}}$ Mention of a trademark, proprietary product, or vendor does not constitute a guarantee or warranty of the product by the USDA or the University of Nebraska, and does not imply its approval to the exclusion of other products or vendors that may be suitable.
} 


\subsection{Nitrate reductase activity}

Nitrate reductase activity was determined using the method described by Klepper (1974). Most recently, fully developed leaf-blade tissue from several plants was cut into $1 \mathrm{~cm}$ long pieces. A $250 \mathrm{mg}$ (fresh weight) sample of this tissue was incubated in a $50-\mathrm{ml}$ beaker for $30 \mathrm{~min}$ at $33^{\circ} \mathrm{C}$ with mild agitation in $5 \mathrm{ml}$ of incubation medium containing both $\mathrm{KNO}_{3}$ and $\mathrm{KH}_{2} \mathrm{PO}_{4}$ at $50 \mu \mathrm{M}$ and $2 \mathrm{~g} \mathrm{l}^{-1}$ of Neutronyx 600 (a nonionic surfactant). Final $\mathrm{pH}$ of the incubation media was adjusted to 7.5 with $3 \mathrm{~N} \mathrm{KOH}$. Nitrite concentration was determined colorometrically at $540 \mathrm{~nm}$ for an aliquot (normally $0.2 \mathrm{ml}$ ) of the incubation medium after addition of $2 \mathrm{ml}$ of a solution containing $0.5 \%$ sulfanilamide, $1.5 \mathrm{~N} \mathrm{HCl}$, and $0.01 \% \alpha$-naphthylenthylene-diaminedi $\mathrm{HCl}$ and brought to a final volume of $4 \mathrm{ml}$ with deionized water. Activities were expressed as $\mu \mathrm{mol}$ of $\mathrm{NO}_{2}$ produced per $\mathrm{kg}$ of fresh weight of leaf-blade tissue per second.

All data were subjected to analysis of variance for a randomized complete block design with a split plot arrangements of treatments. Tillage treatments were assigned to whole plots and nitrogen fertilizer rate treatment was assigned to subplots. Similar data col- lected several times within a growing season were analyzed independently.

\section{Results and discussion}

\subsection{Root growth}

Modifications in cultural practices change soil properties which may, in turn, influence crop growth and development. Wilhelm et al. (1982) reported that the tillage and residue management practices in this study significantly affected root distributions and growth in 1978. The greatest root weight was found in the no-till treatment and the least with the sub-till treatment (Table 1). Nitrogen application did not affect root weight.

During 1979, root distribution with depth was similar to that reported for 1978 (Wilhelm et al., 1982), but the tillage and $N$ fertilizer treatments had no effect on root weight. Though differences between treatments were not significant in 1979 due to the combined influences of relatively similar amounts of root weight produced under all fallow tillage and $\mathrm{N}$ fertilizer treatments and high variation which is characteristic of all measurements of root mass or length

Table 1

Root dry matter of winter wheat grown at the Previously Cultivated site in 1978 and 1979.

\begin{tabular}{|c|c|c|c|c|c|c|c|}
\hline \multirow[t]{3}{*}{ Fallow tillage } & \multirow{3}{*}{$\begin{array}{l}\text { Nitrogen } \\
\text { rate }\left(\mathrm{kg} \mathrm{ha}^{-1}\right)\end{array}$} & \multicolumn{6}{|c|}{ Root weight $\left(\mathrm{kg} \mathrm{ha}^{-1}\right)$} \\
\hline & & \multicolumn{3}{|l|}{1978} & \multicolumn{3}{|l|}{1979} \\
\hline & & $28 \mathrm{Mar}$ & 3 May & 8 June & 18 April & 24 May & 27 June \\
\hline Plow & 0 & 51 & 374 & 642 & 103 & 325 & 550 \\
\hline Sub-till & & 119 & 134 & 332 & 456 & 391 & 769 \\
\hline No-till & & 125 & 605 & 660 & 136 & 396 & 703 \\
\hline Plow & 45 & 36 & 275 & 452 & 174 & 443 & 555 \\
\hline Sub-till & & 48 & 342 & 503 & 215 & 404 & 495 \\
\hline No-till & & 83 & 496 & 606 & 61 & 407 & 638 \\
\hline $\operatorname{LSD}_{(0.05)}$ & & ns & 56 & 70 & ns & ns & ns \\
\hline Plow & & 44 & 325 & 547 & 139 & 384 & 553 \\
\hline Sub-till & & 84 & 238 & 417 & 336 & 398 & 632 \\
\hline No-till & & 104 & 551 & 633 & 99 & 402 & 670 \\
\hline $\operatorname{LSD}_{(0.05)}$ & & ns & 79 & ns & ns & $\mathrm{ns}$ & $\mathrm{ns}$ \\
\hline & 0 & 98 & 371 & 545 & 232 & 371 & 674 \\
\hline & 45 & 57 & 371 & 520 & 163 & 418 & 563 \\
\hline $\operatorname{LSD}_{(0.05)}$ & & $\mathrm{ns}$ & ns & ns & ns & $\mathrm{ns}$ & ns \\
\hline
\end{tabular}


(Schafer and Nielsen, 1981), some similarities were apparent between results from 1978 and 1979. Comparing fallow tillage means at the final sampling (about mid-grain fill) in both years, the greatest root weight was found with the no-till treatment. Between the two years, root weight was similar for the plow $\left(\sim 550 \mathrm{~kg} \mathrm{ha}^{-1}\right)$ and the no-till $\left(\sim 650 \mathrm{~kg} \mathrm{ha}^{-1}\right)$ treatments. However, root weight for the sub-till treatment varied more than $200 \mathrm{~kg} \mathrm{ha}^{-1}$ between the two years. Reasons for the greater season-to-season variation are not known; but in the Previously Cultivated site, the sub-till treatment tended to be the treatment which produced the least grain and residue over the course of the experiment, especially when no fertilizer was applied (Lyon et al., 1998). Soil water content may have also played a role in the variation in root tissue produced. Averaged over the duration of the study, soil water content at planting was least for sub-till $\left(0.180 \mathrm{~kg} \mathrm{~kg}^{-1}\right)$ compared to $0.181 \mathrm{~kg} \mathrm{~kg}^{-1}$ for plow (not different from sub-till) and $0.187 \mathrm{~kg} \mathrm{~kg}^{-1}$ for notill.
Averaged over tillage and $\mathrm{N}$ treatments and years, ca. $575 \mathrm{~kg} \mathrm{ha}^{-1}$ of root tissue was present at the last sampling (about mid-grain fill; Table 1) in 1978 and 1979. This is ca. $7 \%$ of the above-ground dry-matter production in 1979 and 1980 (Table 2). This number is somewhat low compared to some published results, but near the range (9-13\%) reported by Barraclough (1984) for winter wheat grown in Britain and within the range (4-17\%) found by Schmidt et al. (1994) in Western Australia.

\subsection{Leaf area and dry matter}

Leaf area and dry-matter distribution characteristics were similar across all treatment combinations in late May 1979 (Table 2). At late grain fill (27 June), SLW for no-till was less compared to the sub-till treatment. Dry-matter production at the same sampling time was greater for the no $\mathrm{N}$ treatment than for the $45 \mathrm{~kg}$ N) ha ${ }^{-1}$ treatment.

Table 2

Leaf area index, specific leaf weight, leaf area ratio, and dry matter of winter wheat grown under several fallow tillage and N-fertilizer application treatments at the Previously Cultivated site in 1979

\begin{tabular}{|c|c|c|c|c|c|}
\hline $\begin{array}{l}\text { Fallow } \\
\text { tillage }\end{array}$ & $\begin{array}{l}\text { Nitrogen } \\
\text { rate }\left(\mathrm{kg} \mathrm{ha}^{-1}\right)\end{array}$ & $\begin{array}{l}\text { Leaf area } \\
\text { index }\end{array}$ & $\begin{array}{l}\text { Specific leaf } \\
\text { weight }\left(\mathrm{g} \mathrm{m}^{-2}\right)\end{array}$ & $\begin{array}{l}\text { Leaf area } \\
\text { ratio }\left(\mathrm{m} \mathrm{kg}^{-2}\right)\end{array}$ & $\begin{array}{l}\text { Dry matter } \\
\left(\mathrm{g} \mathrm{m}^{-2}\right)\end{array}$ \\
\hline \multicolumn{6}{|l|}{23 May } \\
\hline \multirow[t]{2}{*}{ Plow } & 0 & 1.92 & 48.8 & 8.8 & 222 \\
\hline & 45 & 1.99 & 51.2 & 8.7 & 228 \\
\hline \multirow[t]{2}{*}{ Sub-till } & 0 & 2.40 & 46.9 & 9.4 & 261 \\
\hline & 45 & 2.69 & 48.4 & 9.1 & 295 \\
\hline \multirow[t]{2}{*}{ No-till } & 0 & 2.89 & 47.4 & 9.8 & 296 \\
\hline & 45 & 2.89 & 46.7 & 9.9 & 286 \\
\hline \multicolumn{6}{|c|}{$\operatorname{LSD}_{(0.05)}$} \\
\hline Tillage & & ns & ns & ns & ns \\
\hline N-rate & & ns & ns & ns & ns \\
\hline $\mathrm{N} * \mathrm{~T}$ & & ns & ns & ns & ns \\
\hline \multicolumn{6}{|l|}{27 June } \\
\hline \multirow[t]{2}{*}{ Plow } & 0 & 0.75 & 81.7 & 8.2 & 981 \\
\hline & 45 & 0.71 & 82.5 & 8.8 & 901 \\
\hline \multirow[t]{2}{*}{ Sub-till } & 0 & 0.78 & 88.6 & 7.8 & 947 \\
\hline & 45 & 0.76 & 86.0 & 7.9 & 874 \\
\hline \multirow[t]{2}{*}{ No-till } & 0 & 0.92 & 74.8 & 9.7 & 940 \\
\hline & 45 & 0.86 & 73.6 & 10.9 & 789 \\
\hline \multicolumn{6}{|c|}{$\operatorname{LSD}_{(0.05)}$} \\
\hline Tillage & & $\mathrm{ns}$ & 10.2 & $\mathrm{~ns}$ & ns \\
\hline N-rate & & $\mathrm{ns}$ & $\mathrm{ns}$ & ns & 49 \\
\hline $\mathrm{N} * \mathrm{~T}$ & & $\mathrm{~ns}$ & $\mathrm{~ns}$ & $\mathrm{~ns}$ & $\mathrm{~ns}$ \\
\hline
\end{tabular}


Table 3

Tiller number, leaf area index, specific leaf weight, leaf area ratio, and dry matter of winter wheat grown under several fallow tillage and Nfertilizer application treatments at the Previously Cultivated site in 1980

\begin{tabular}{|c|c|c|c|c|c|c|}
\hline $\begin{array}{l}\text { Fallow } \\
\text { tillage }\end{array}$ & $\begin{array}{l}\text { Nitrogen } \\
\text { rate }\left(\mathrm{kg} \mathrm{ha}^{-1}\right)\end{array}$ & $\begin{array}{l}\text { Tiller number } \\
\text { (tiller } \mathrm{m}^{-2} \text { ) }\end{array}$ & $\begin{array}{l}\text { Leaf area } \\
\text { index }\end{array}$ & $\begin{array}{l}\text { Specific leaf } \\
\text { weight }\left(\mathrm{g} \mathrm{m}^{-2}\right)\end{array}$ & $\begin{array}{l}\text { Leaf area } \\
\text { ratio }\left(\mathrm{m}^{2} \mathrm{~kg}^{-1}\right)\end{array}$ & $\begin{array}{l}\text { Dry matter } \\
\left(\mathrm{g} \mathrm{m}^{-2}\right)\end{array}$ \\
\hline \multicolumn{7}{|l|}{13 May } \\
\hline \multirow[t]{2}{*}{ No-till } & 0 & 1174 & 1.70 & 45.3 & 9.7 & 174 \\
\hline & 45 & 1034 & 1.29 & 45.7 & 9.6 & 134 \\
\hline \multirow[t]{2}{*}{ Sub-till } & 0 & 973 & 2.21 & 44.4 & 9.1 & 242 \\
\hline & 45 & 1084 & 2.06 & 43.8 & 10.0 & 206 \\
\hline \multirow[t]{2}{*}{ Plow } & 0 & 890 & 1.90 & 45.6 & 9.0 & 211 \\
\hline & 45 & 1232 & 2.13 & 43.2 & 9.4 & 228 \\
\hline \multicolumn{7}{|c|}{$\operatorname{LSD}_{(0.05)}$} \\
\hline Tillage & & ns & 0.39 & ns & $\mathrm{ns}$ & 40 \\
\hline N-rate & & ns & $\mathrm{ns}$ & $\mathrm{ns}$ & 0.4 & ns \\
\hline $\mathrm{N} * \mathrm{~T}$ & & ns & $\mathrm{ns}$ & ns & ns & ns \\
\hline \multicolumn{7}{|l|}{11 June } \\
\hline \multirow[t]{2}{*}{ Plow } & 0 & 767 & 0.85 & 63.3 & 1.2 & 696 \\
\hline & 45 & 935 & 1.30 & 63.9 & 1.8 & 731 \\
\hline \multirow[t]{2}{*}{ Sub-till } & 0 & 729 & 1.07 & 62.2 & 1.4 & 740 \\
\hline & 45 & 889 & 1.66 & 61.9 & 2.1 & 804 \\
\hline \multirow[t]{2}{*}{ No-till } & 0 & 736 & 0.82 & 65.8 & 1.3 & 629 \\
\hline & 45 & 780 & 1.12 & 65.6 & 1.8 & 634 \\
\hline \multicolumn{7}{|c|}{$\operatorname{LSD}_{(0.05)}$} \\
\hline Tillage & & ns & ns & ns & ns & ns \\
\hline $\mathrm{N}$-rate & & $\mathrm{ns}$ & 0.41 & $\mathrm{~ns}$ & ns & $\mathrm{ns}$ \\
\hline $\mathrm{N} * \mathrm{~T}$ & & ns & $\mathrm{ns}$ & ns & ns & $\mathrm{ns}$ \\
\hline
\end{tabular}

${ }^{a}$ Only two blocks sampled on 13 May.

A general lack of treatment influence on leaf area and dry-matter characteristics was noted at the 13 May, 1980 sampling (Table 3), although leaf area index (LAI; 1.49 vs. 2.08$)$ and dry matter (1.54 vs. $2.22 \mathrm{~g} \mathrm{~m}^{-2}$ ) for no-till was less than for the other treatments. By 11 June 1980, the tillage effects were no longer observed. However, greater LAI (0.91 vs. 1.36$)$ and leaf area ratio (LAR; 1.30 vs. $\left.1.91 \mathrm{~m}^{2} \mathrm{~kg}^{-1}\right)$ were found for the $45(\mathrm{~kg} \mathrm{~N}) \mathrm{ha}^{-1}$ treatments than for the no $\mathrm{N}$ treatment. Although these parameters both measure the size of the photosynthetic apparatus of the plant (one in absolute terms, LAI; the other in relative terms, LAR), the total size of the plants was similar (dry matter; $706 \mathrm{~g} \mathrm{~m}^{-2}$ ). The lack of an $\mathrm{N}$-treatment effect in the earlier sampling may have been related to the timing of $\mathrm{N}$ application. Nitrogen was applied in mid-April, one month prior to the first sampling. Plants may not have had time to respond to addition of $\mathrm{N}$ before sampling, but did so before the June sampling. At physiological maturity (10 July, 1980) more total dry matter was produced when $\mathrm{N}$ was applied to no-till and plow treatments; however, $\mathrm{N}$ application reduced total drymatter production for the sub-till treatment (Table 4). The grain yield interaction between tillage and $\mathrm{N}$ application was apparent for the plow and sub-till treatments, and was in the same direction as that for dry-matter production. Averaged over all tillage treatments, more grain was produced when $\mathrm{N}$ was not applied.

During 1981 (Table 5), tillage treatments did not affect dry-matter and leaf area parameters. Addition of $\mathrm{N}$ resulted in increased tiller numbers at the May sampling ( 943 vs. 1113 tillers $\mathrm{m}^{-2}$ ). Although the total number of tillers was less at the July sampling, the application of $\mathrm{N}$ resulted in greater tiller survival (Table 4; 675 vs. 769 tillers $\mathrm{m}^{-2}$ ). Greater amounts of total dry matter and grain were also produced with the addition of $\mathrm{N}$ during this cropping season. 
Table 4

Total dry matter, grain yield, and tiller number of winter wheat grown under several fallow tillage and N-fertilizer application treatments at the Previously Cultivated site

\begin{tabular}{|c|c|c|c|c|}
\hline $\begin{array}{l}\text { Fallow } \\
\text { tillage }\end{array}$ & $\begin{array}{l}\text { Nitrogen rate } \\
\left(\mathrm{kg} \mathrm{ha}^{-1}\right)\end{array}$ & $\begin{array}{l}\text { Tiller number } \\
\text { (tiller } \mathbf{m}^{-2} \text { ) }\end{array}$ & $\begin{array}{l}\text { Total dry } \\
\text { matter }\left(\mathrm{g} \mathrm{m}^{-2}\right)\end{array}$ & $\begin{array}{l}\text { Grain yield } \\
\left(\mathrm{Mg} \mathrm{ha}^{-1}\right)\end{array}$ \\
\hline \multicolumn{5}{|c|}{10 July, 1980} \\
\hline \multirow[t]{2}{*}{ Plow } & 0 & 704 & 636 & 1.77 \\
\hline & 45 & 730 & 701 & 1.86 \\
\hline \multirow[t]{2}{*}{ Sub-till } & 0 & 699 & 731 & 2.34 \\
\hline & 45 & 805 & 642 & 1.73 \\
\hline \multirow[t]{2}{*}{ No-till } & 0 & 673 & 704 & 2.12 \\
\hline & 45 & 715 & 731 & 1.93 \\
\hline \multicolumn{5}{|c|}{$\operatorname{LSD}_{(0.05)}$} \\
\hline Tillage & & ns & ns & ns \\
\hline N-rate & & ns & ns & 0.13 \\
\hline $\mathrm{N} * \mathrm{~T}$ & & ns & 59 & 0.23 \\
\hline \multicolumn{5}{|c|}{15 July, 1981} \\
\hline \multirow[t]{2}{*}{ No-till } & 0 & 749 & 708 & 2.32 \\
\hline & 45 & 850 & 785 & 2.85 \\
\hline \multirow[t]{2}{*}{ Sub-till } & 0 & 630 & 662 & 2.37 \\
\hline & 45 & 694 & 848 & 2.72 \\
\hline \multirow[t]{2}{*}{ Plow } & 0 & 648 & 793 & 2.54 \\
\hline & 45 & 764 & 836 & 2.52 \\
\hline \multicolumn{5}{|c|}{$\operatorname{LSD}_{(0.05)}$} \\
\hline Tillage & & ns & $\mathrm{ns}$ & ns \\
\hline N-rate & & 95 & 69 & 0.21 \\
\hline $\mathrm{N} * \mathrm{~T}$ & & ns & $\mathrm{ns}$ & ns \\
\hline
\end{tabular}

Table 5

Tiller number, leaf area index, specific leaf weight, leaf area ratio, and dry matter of winter wheat grown under several fallow tillage and $\mathrm{N}$ fertilizer application treatments at the Previously Cultivated site, 11 May, 1981

\begin{tabular}{|c|c|c|c|c|c|c|}
\hline $\begin{array}{l}\text { Fallow } \\
\text { tillage }\end{array}$ & $\begin{array}{l}\text { Nitrogen rate } \\
\left(\mathrm{kg} \mathrm{ha}^{-1}\right)\end{array}$ & $\begin{array}{l}\text { Tiller number } \\
\text { (tiller } \mathrm{m}^{-2} \text { ) }\end{array}$ & $\begin{array}{l}\text { Leaf area } \\
\text { index }\end{array}$ & $\begin{array}{l}\text { Specific leaf } \\
\text { weight }\left(\mathrm{g} \mathrm{m}^{-} 2\right)\end{array}$ & $\begin{array}{l}\text { Leaf area } \\
\text { ratio }\left(\mathrm{m}^{2} \mathrm{~kg}^{-1}\right)\end{array}$ & $\begin{array}{l}\text { Dry matter } \\
\left(\mathrm{g} \mathrm{m}^{-2}\right)\end{array}$ \\
\hline \multirow[t]{2}{*}{ Plow } & 0 & 942 & 2.25 & 48.8 & 6.9 & 326 \\
\hline & 45 & 1152 & 2.29 & 46.1 & 7.4 & 318 \\
\hline \multirow[t]{2}{*}{ Sub-till } & 0 & 996 & 2.82 & 49.3 & 6.7 & 418 \\
\hline & 45 & 1099 & 2.78 & 50.6 & 7.2 & 385 \\
\hline \multirow[t]{2}{*}{ No-till } & 0 & 892 & 2.40 & 48.3 & 6.2 & 385 \\
\hline & 45 & 1089 & 2.54 & 50.2 & 6.7 & 390 \\
\hline \multicolumn{7}{|c|}{$\operatorname{LSD}_{(0.05)}$} \\
\hline Tillage & & ns & ns & ns & ns & $\mathrm{ns}$ \\
\hline N-rate & & 136 & ns & ns & ns & 47 \\
\hline $\mathrm{N} * \mathrm{~T}$ & & ns & ns & ns & ns & $\mathrm{ns}$ \\
\hline
\end{tabular}

\subsection{Nitrate reductase activity}

Broder et al. (1984) reported that the surface $30 \mathrm{~cm}$ of non-tilled soil can be characterized as having less
$\mathrm{NO}_{3}-\mathrm{N}$ compared to conventionally tilled soils. To evaluate the effects of this tillage-induced change in the soil environment on plant physiological processes, nitrate reductase activity of winter wheat leaf tissue 
Table 6

Nitrate reductase activity at several sampling dates during 1979 through 1981 of winter wheat grown under several fallow tillage and Nfertilizer application treatments at the Previously Cultivated site

\begin{tabular}{|c|c|c|c|c|c|c|c|}
\hline \multirow[t]{3}{*}{ Fallow tillage } & \multirow{3}{*}{$\begin{array}{l}\text { Nitrogen rate } \\
\left(\mathrm{kg} \mathrm{ha}^{-1}\right)\end{array}$} & \multicolumn{6}{|l|}{ Date } \\
\hline & & \multicolumn{3}{|l|}{1979} & \multicolumn{2}{|l|}{1980} & \multirow{2}{*}{$\frac{1981}{11 \text { May }}$} \\
\hline & & $\begin{array}{l}17 \text { April } \\
\text { nitrate red }\end{array}$ & $\begin{array}{l}22 \text { May } \\
\text { activity ( }(r\end{array}$ & $\begin{array}{l}26 \text { June } \\
\left.\left.\mathrm{O}_{2}\right) \mathrm{kg}^{-1} \mathrm{~s}^{-1}\right)\end{array}$ & 13 May & 26 June & \\
\hline \multirow[t]{2}{*}{ No-till } & 0 & 11.2 & 4.1 & 4.3 & 9.0 & 1.6 & 8.5 \\
\hline & 45 & 13.3 & 8.6 & 6.3 & 15.3 & 2.9 & 15.8 \\
\hline \multirow[t]{2}{*}{ Sub-till } & 0 & 12.2 & 6.2 & 6.5 & 11.6 & 1.3 & 14.8 \\
\hline & 45 & 11.1 & 7.2 & 7.8 & 18.3 & 3.6 & 16.7 \\
\hline \multirow[t]{2}{*}{ Plow } & 0 & 11.9 & 2.8 & 5.2 & 12.8 & 1.9 & 8.6 \\
\hline & 45 & 11.2 & 6.7 & 6.3 & 15.3 & 3.4 & 13.6 \\
\hline \multicolumn{8}{|l|}{$\operatorname{LSD}_{(0.05)}$} \\
\hline Tillage & & ns & ns & $\mathrm{ns}$ & $\mathrm{ns}$ & $\mathrm{ns}$ & $\mathrm{ns}$ \\
\hline $\mathrm{N}$-rate & & ns & 1.2 & 0.6 & 1.3 & 0.6 & 3.0 \\
\hline $\mathrm{N} * \mathrm{~T}$ & & 1.5 & 2.0 & ns & 2.2 & ns & $\mathrm{ns}$ \\
\hline
\end{tabular}

was compared across treatments. With less $\mathrm{NO}_{3}-\mathrm{N}$ in the no-till system, it was hypothesized that nitrate reductase activity of winter wheat would be reduced.

Data from 1979 (Table 6) at the 17 April sampling date (prior to $\mathrm{N}$ application) showed nitrate reductase activity was greatest for winter wheat produced with sub-till and plow when no $\mathrm{N}$ had been applied in previous years. However, with no-till the opposite was true. After $\mathrm{N}$ application, nitrate reductase activity was consistently greater for treatments receiving $\mathrm{N}$. The greater activity of nitrate reductase after $\mathrm{N}$ applications was also observed in 1980 and 1981. Tillage was not a significant source of variation for any of the evaluation times (in any year). However, the $\mathrm{N}$ by tillage interaction term was significant on 17 April and 22 May, 1979 and 13 May, 1980. The 17 April interaction was discussed in the foregoing. On 22 May, 1979, the interaction was caused by the magnitude of the difference between no $\mathrm{N}$ and $45(\mathrm{~kg}$ $\mathrm{N}) \mathrm{ha}^{-1}$ treatments among the tillage practices. For no-till and plow, addition of $\mathrm{N}$ more than doubled nitrate reductase activity; however, a sub-till addition of $\mathrm{N}$ caused only a $17 \%$ increase in activity. Again on 13 May, 1980, the interaction was caused by a difference in magnitude of nitrate reductase activity with addition of $\mathrm{N}$. With addition of $\mathrm{N}$, nitrate reductase activity increased $60-70 \%$ for the no-till and sub-till treatments, but only $20 \%$ for the plow treatment. The initial hypothesis was not supported by these data.
Nitrate reductase activity of no-till was always similar to that of other tillage treatments.

\section{Conclusion}

Modification of the soil environment by tillage practices had a substantial influence on wheat root development and distribution patterns. A greater mass of root tissue was observed on 3 May, 1978 with the no-till treatment than with the plow or sub-till treatments. Ellis and Barnes (1980) also found greater root counts in direct-drilled compared to wheat planted into plowed soil. At other sampling times in both 1978 and 1979, tillage treatments had similar root masses. Root growth was sensitive to soil layers with greater soil strength (Wilhelm et al., 1982). This result is similar to the findings of Martino and Shaykewich (1994) at the Marquette site where they observed a reduced rooting below a layer with greater penetration resistance in the zero tillage treatment. In general, leaf area and mid-season dry-matter production did not respond to tillage practices. Nitrogen fertilization did not have a consistent effect on dry-matter production when measured during the growing season as was done here. This result is similar to that reported by Fenster and Peterson (1979) and Merrill et al. (1996): In contrast, Lyon et al. (1998) reported greater residue yields with addition of $\mathrm{N}$ over the 26-year duration of this study. The data reported here were collected after 
about 10 years of treatment. Under conditions of this study, nitrate reductase activity proved to be a poor indicator of level of nitrate nutrition.

\section{Acknowledgements}

This paper is a joint contribution of the U.S. Department of Agriculture's Agricultural Research Service and the Agricultural Research Division of the University of Nebraska. Published as Journal Series No. 12031.

\section{References}

Barraclough, P.B., 1984. The growth and activity of winter wheat roots in the field: Root growth of high-yielding crops in relation to shoot growth. J. Agric. Sci. Camb. 103, 439-442.

Bennic, A.T.P., Taylor, H.M., Georgen, P.G., 1987. An assessment of the core-break method for estimating rooting density of different crops in the field. Soil Tillage Res. 9, 347-353.

Broder, M.W., Doran, J.W., Peterson, G.A., Fenster, C.R., 1984. Fallow tillage influence on spring populations of soil nitrifiers, denitrifiers, and available nitrogen. Soil Sci. Soc. Amer. J. 48, 1060-1067.

Bond, J.J., Power, J.F., Willis, W.O., 1971. Tillage and crop residue management during seedbed preparation for continuous spring wheat. Agron. J. 63, 789-793.

Chantarotwong, W., Huffaker, R.C., Miller, B.L., Granstedt, R.C., 1976. In vivo nitrate reduction in relation to nitrate uptake, nitrate content, and in vitro nitrate reductase activity in intact barley seedlings. Plant Physiol. 57, 519-522.

Ellis, F.B., Barnes, B.T., 1980. Growth and development of root systems of winter cereals grown after different tillage methods including direct drilling. Plant Soil 55, 283-295.

Fenster, C.R., Peterson, G.A., 1979. Effect of no-tillage fallow as compared to conventional tillage in a wheat-fallow system. Nebr. Agric. Exp. Stn. Res. Bull. No. 289.

Klepper, L., 1974. A mode of action of herbicides: Inhibition of the normal process of nitrite reduction. Nebr. Agric. Exp. Stn. Res. Bull, No. 259.
Lyon, D., Stroup, W.W., Brown, R.E., 1998. Crop production and soil water storage in long-term winter wheat-fallow tillage experiments. Soil Tillage Res. 49, 19-27.

Martino, D.L., Shaykewich, C.F., 1994. Root penetration profiles of wheat and barley as affected by soil penetration resistance in field conditions. Can. J. Soil Sci. 74, 193-200.

Merrill, S.D., Black, A.L., Bauer, A., 1996. Conservation tillage affects root growth of dryland spring wheat under drought. Soil Sci. Soc. Amer. J. 60, 575-583.

Milthorpe, F.L., Moorby, J., 1974. An Introduction to Crop Physiology. Cambridge University Press, Cambridge, pp. 202.

Neerajdatta, Rao, L.V.M., Guha-Mukherjee, S., Sopory, S.K., 1981. Regulation of nitrate reductase activity by ammonium in wheat. Plant Sci. Lett. 20, 305-313.

Oussible, M., Crookston, R.K., Larson, W.E., 1992. Subsurface compaction reduces the root and shoot growth and grain yield of wheat. Agron. J. 84, 34-38.

Peterson, C.M., Klepper, B., Pumphrey, F.V., Rickman, R.W., 1984. Restricted rooting decreases tillering and growth of winter wheat. Agron. J. 76, 861-863.

Power, J.F., Wilhelm, W.W., Doran, J.W., 1986. Recovery of fertilizer nitrogen by wheat as affected by fallow method. Soil Sci. Soc. Amer. J. 50, 1499-1503.

Schafer, W.M., Nielsen, G.A., 1981. Root biomass calculation using a modified counting technique. J. Range Manage. 34, 237-245.

Schmidt, C.P., Belford, R.K., Tennent, D., 1994. Effect of different direct drilling and conventional sowing techniques on soil strength, root growth, and grain yield of wheat on sandplain soils in Western Australia. Aust. J. Agric. Res. 45, 547-564.

Wilhelm, W.W., Bouzerzour, H., Power, J.F., 1989. Soil disturbance-residue management effect on winter wheat growth and yield. Agron. J. 81, 581-588.

Wilhelm, W.W., Doran, J.W., Power, J.F., 1986. Corn and soybean yield response to crop residue management under no-tillage production systems. Agron. J. 78, 184-189.

Wilhelm, W.W., Mielke, L.N., 1988. Winter wheat growth in artificially compacted soil. Can. J. Plant Sci. 68, 527-535.

Wilhelm, W.W., Mielke, L.N., Fenster, C.R., 1982. Root development of winter wheat as related to tillage practices in Western Nebraska. Agron. J. 74, 85-88.

Wilhelm, W.W., Schepers, J.S., Mielke, L.N., Doran, J.W., Ellis, J.R., Stroup, W.W., 1987. Dryland maize development and yield resulting from tillage and nitrogen fertilization practices. Soil Tillage Res. 10, 167-179. 